\title{
How "Commonsense" Notions of Race, Class and Gender Infiltrate Families Formed across the Color Line
}

\author{
Eileen T. Walsh \\ California State University, Fullerton, USA \\ Email: ewalsh@fullerton.edu \\ Received August $15^{\text {th }}, 2011$; revised September $8^{\text {th }}, 2011$; accepted November $12^{\text {th }}, 2011$
}

\begin{abstract}
This research presents data from in-depth interviews of sixty adults in Southern California who have formed families across the black/white color line. In a societal context where normative family formation remains mono-racial, many adults in multiracial families manage their social performances to mitigate the stigma associated with their unusual family pattern or to challenge social expectations associated with race, class, and gender. Their stories reveal how they deploy strategic exaggerations of gender and stereotypes of social class in their day to day lives. These deployments operate to manage social interactions when confronting commonsense expectations about what it means to be a man or woman who trespasses the color line in family formation.
\end{abstract}

Keywords: Gender Performance; Multiracial Family; Racial Formations; Social Class Performances

\section{Introduction}

Family, as an institution, remains a bastion of racial segregation for whites and blacks in this century in the United States (Fu, 2001; Qian, 1997; Fields \& Casper, 2001). Although interracial marriages have increased in the past three decades, marriages across the black white color line seldom occur (Fu, 2001; Gullickson, 2006; Qian, 1997; Qian \& Lichter, 2007). In part due to their rarity, and in part due to the historical stigma associated with such unions, multiracial families are subject to social surveillance in their everyday lives (Childs, 2005; Dalmage, 2000; McNamera et al., 1999; Rosenblatt et al., 1995).

Notions of gender and social class were and remain as important in the creation and recreation of racial disparities as is the ideology of white supremacy that enforces and patrols the boundary between those who think of themselves as white and those who have been assigned by historical practices to social locations of racial categories (Ferber, 1998; Pascoe, 2010; Wallenstein, 2002). The interview excerpts illustrate that ideas of race, gender and social class are inextricably entangled with understandings of both the color line and racial ideologies. By examining what multiracial family members say about their race and gender performances, this research exposes the gendered ways that race is socially constructed. Second, the data illustrate how gender conflates with social class and continues to function in contemporary society as an essential prop of the historical racial hierarchy. Although especially true in the social construction of white femininity, with its emphasis on purity and racial purity that forms the ideological linchpin for white supremacy, ideations of femininity/masculinity and respectability/class operate as powerful social constraints on many of the men and women who have formed families across the color line.

\section{Background}

Despite generation after generation of academic and popular writings declaring that the country was the verge of an explosive increase in marriages across the color line, marriages across the black white color line remain the most unusual pattern of family formation with the flattest rate of growth since the 1960's (Sanjek, 1994). The US Census Bureau estimates that of the fifty-nine (59) million married couples in 2000, fewer than one million were comprised of partners of two different races. Of the couples where partners were two or more races, less than a half million had one black partner and one white partner. Analysis of the same data indicates that fewer than half of one percent of black married women in 2000 had a white spouse; fewer than $5 \%$ of all black married men had a partner of another race-with the majority married to women of Asian or Hispanic descent (Qian \& Lichter, 2001; Lichter \& Qian, 2004).

For decades, demographers have noted the low incidence of black/white marriages and the inverted gender pattern (Heer, 1966; Heer, 1974; Kalmijn, 1993; Monahan, 1976; Quin, 1997). The literature posits theories to explain the scarcity of black/ white marriages and the unusually low exogamy rate for black women (Kaba, 2011; Tucker \& Mitchell-Kernan, 1998). No other the research, however, has compared white and black men and women in integrated families to illuminate their understandings of race, their experiences with broader social networks and how gender challenges shape their encounters with others. Some qualitative data suggests that men and women married across the color line experience different types of challenges about their gender and race. White women report a sense of loss of their femininity and their whiteness and Black men report a loss of their racial authenticity by marriages across the color line (Dalmage, 2000; Reddy, 1994; Rosenblatt et al., 1995). This research examines those experiences to shed light on how these gender challenges operate as social control mechanisms to maintain racial boundaries.

\section{Conceptual Framework}

Multiracial families are at the fulcrum in "the socio-historical 
process by which racial categories are created, inhabited, transformed, and destroyed" (Omi \& Winant, 1994: p. 55). Stories from men and women in multiracial families illustrate the gendered nature of race as an important but under researched dynamic of power in their experiences. Shifting racial boundaries are at the heart of the multiracial family project. It is important both to document the structural aspects that inhibit formation of families across the color line and to interrogate the cultural meanings that circulate about race, class and gender on the edge of the color line. This research adopts the definition of race as concept, socially created and negotiated, that changes in different historical epochs and in different cultures (Lopez, 1996; Roediger, 1999).

This research focuses on the process adults who form these families create, reproduce or challenge mainstream understandings of race, class and gender. They engage this process in concert with other social actors in their everyday lives. It is in the narratives, conversations and life stories of those who live on the color line that many others turn either to authenticate their own commonsense understandings about race and gender or to puzzle out questions of race, class and gender that the multiracial family poses to our commonsense understandings.

The persistent racial segregation of blacks and whites in the most intimate institution, families, contradicts all predictions that the progression of racial integration in the 20th century would continue from schools and workplaces to the selection of marriage partners (Billingsley, 1992; Heer, 1974; Kalmijn, 1993; Myrdal, 1945; Parks, 1926; Quan, 1994; Washington, 1993). The fact that the family, as an institution remains a bastion of racial segregation for Whites and Blacks in this century runs contrary to expectations and probabilities. If race were not a factor in mate selection, the rates of intermarriage since the US Supreme Court decriminalized such pairings would be much greater than what occurs. The continuing significance of race and social distance from Blacks is clearly evident, however, in America's marriage patterns (Bonilla-Silva, 2002; Harris \& Ono, 2005).

Common sense discourse about families formed across the color line remains an important prop in the hegemonic racial project that curtails intimate transgressions across the color line in this country. In an age of color blind ideology, what social processes remain in place to curtail family formation across the color line? By examination of how those in multiracial families bump up against commonsense notions of race, class and gender, this research sheds light on some ways that the cultural legacy of historic laws along with the ideology of white supremacy seep into the actual lived daily experiences of those in multiracial families.

\section{Methods}

A burgeoning literature makes compelling arguments that social phenomena must be interpreted through a framework that seeks to understand the ways meaning emerges from interactions and reminisces (Gubrium \& Holstein, 2002; Weiss, 1994). This framework informed the in-depth interviews which form the basis of this research.

I interviewed a total of sixty (60) adults living in Southern California who have formed families across the powerful black white racial divide. I choose to concentrate on this particular subset of multiracial families for five reasons of particular theoretical interest. First, blacks are the only group in the United
States whose racial identity has been historically based on the "one-drop" rule of hypo-descent: any known ancestor of socalled Negro blood consigned one to the black side of the color line (Davis, 1991; Pascoe, 2010; Spencer, 1999). Second, whites form the only group whose membership eligibility depends on the myth of racial purity requiring the documentation of ancestors and creation a family tree (Dalmage, 2004). Third, one persistent feature in the inconsistent patchwork of myriad anti-miscegenation laws written from colony to colony and from state to state, was the prohibition against blacks marrying whites (Pascoe, 2010; Wallenstein, 2002). Fourth, kinship ties between blacks and whites remain the most uncommon type of multiracial family. Compared to other children of racially diverse parents, black and white parents have the smallest percent of multiracial births; when compared to intermarriage rates among all other racial groups, the growth rate for black white marriages remains flat (Sanjeck, 1994; Quan, 1997; Tucker et al., 1999). Fifth, in an interesting twist, the gender pattern of black/ white family formation inverts the pattern that prevails in every other exogamous marriage. Typically, white men out-marry women from other racial categories and women from so-called minority groups out-marry more than men from racial minorities. In contrast, most families that form across the black white color line continue to be comprised of a black husband and a white wife (Zebrowsky, 1999). In all, these five reasons suggest that the black white divide is not only the most persistent and least permeable crossing of the color line, but one where something different is going on.

I recruited respondents through convenience, chain and snowball sampling with a purposive sampling technique. The final sample is comprised of thirty women and thirty men; thirty Blacks and thirty Whites: with fifteen respondents in each of the four gender/race cells. The interviews lasted at least one and a half hours and typically three hours.

While not representative of all adults in Southern California who formed families across the color line, the interview data are intended to tap into a wide range of gendered narratives about life on the color line. In this endeavor, it is necessary to make some generalizations at the risk of over-simplification. To avoid making erroneous generalizations, each of the respondent's quotes are put in context within a summary of what they reported in the in-depth interview. In addition, because Americans "read" race off the body, I include a brief description of the respondent to allow the reader access to each respondent's presentation of self which is central to gender and class performance.

\section{Results and Discussion}

\section{Femininity and Class on the Color Line}

It is often said that only the worst Negroes and lowest Whites intermarry (duBois, 1967: p. 358).

Drawing on the conventional wisdom circulating as commonsense in 1930, W. E. B. DuBois refutes the assertion that intermarriage is highest among the class with least prestige and property using empirical data on a sample of 9000 to show interracial marriage at that time was most likely among those who had the most contact. Nonetheless, his frame of the issue reflects long held and enduring notions about the types of individuals who intermarry.

At the time I interviewed Jeanne she had been married to 
Lou Jamison for 49 years. The 72 year old, trim Jeanne, wore a jogging outfit for the interview in her home in a gated desert community. With graying nappy hair and deeply tanned, she was every bit as dark complexioned as her café au lait husband who greeted me before retiring to the patio. A self-described "red diaper" baby she recounts being dragged from meetings of socialists to gatherings of communists during her childhood with parents whose counter-culture beliefs influenced her deeply. Explaining that her activist parents had approved of her dating a black man, Jeanne:

My parents were thrilled when we started seeing each other. In 1950s having your daughter going with a Neeg-roe (pronounced deliberately in two emphatic syllables) was like an endorsement for them, "Look everyone; we raised her with the right values". It was a validation for them.

Nawt so-oo happy when we decided to get married.

But it wasn't about the color line. It was that we were getting too (long pause) too middle-class. That was the worst insult my parents could ever say, "middle-class". Jeanne Jamison, age 72 at interview, married a black attorney in 1954.

Jeanne Jamison gave many examples of using her husband's prominence and their social class status to "rise above" criticism. Over the years she used a defiance of convention along with the safe security of social class position as shields strategically employed to deflect criticism, social ostracism and negative comments from others. She gave examples from "uppity" neighbors in her North east urban neighborhood to school officials who were chagrined to discover "who we were".

She spoke at great length of involvement with progressive cooperatives for schools and food to charity work where she refused to wear "the expected girly costumes". She took great pleasure in asserting the many ways she defied conventional performance of femininity-even at the disapproval of her mother-in-law.

In 1964, when a suburban Los Angeles school teacher from a working class background and her black fiancé married, they experienced a very different social and cultural context than the Jamison couple had in metropolitan Northeastern city a decade before. Trudy, a young looking, impeccably coifed 64 year old blonde, greeted me at her door wearing a holiday themed sweater set and dangling jack-o-lantern earrings that matched the embroidered pumpkins on her black velvet flats. We began the interview surrounded by dozens of silver-framed family photographs: a chronicle of vacations, birthdays, holidays and personal events spanning the past fifty years.

Nobody would rent to us when we went looking together. At least, not a place in a decent (pronounced with emphasis on both syllables) neighborhood. Trudy Graham, age 64 at intervie married to a black teacher in 1964.

The use of "decent" to describe a neighborhood she was willing to live in and her frequent use "good" in referring to families are two devices echoed by many interviewed. These rhetorical props allude to social class, but are code words often used by whites to avoid a direct discussion of race.

Their friends, with one exception, “just happen to be” white. Their daughter attended private schools as a child, had "almost all white friends" and the family has had virtually no contact over the years with Phillip's family. The Grahams' strategies for living with the social context of the color line they encountered during the 1960's was to find sympathetic friends, avoid any controversial discussions of race, achieve a comfortable lifestyle and revert to a social network of whites who were comfortable with Phillip.

Lucy is a high school English teacher, raised by white collar parents in Southern California. This interview took place in her older suburban tract home in an exclusive neighborhood of horse properties. Lucy described her ideas about the color line.

My sisters and I-all three of us girls knew that there was this invisible line. Invisible, but real. That line dictated where you shopped, where you lived, what you did. It was never said. It was kinda like everyone just knew. You know, we never had anything to do with kids who lived south of the freeway-nobody did, we just knew they weren't like us. They were white, but they were from the other side of (names) town (pause).

I honestly don't remember ever seeing any black person anywhere in Orange County until I was a teenager. But I knew they were out there. I knew they were out there somewhere. And I knew that bringing home a black guy would seem to my dad like the biggest insult-like maybe he'd feel like he hadn't been a good dad. Like I'd let him down. Nothing was ever said. We girls just knew. Lucy King. 32 years old at interview. Married a black professional athlete in 1997.

Lucy deployed naiveté and racial innocence throughout the interview to underscore her femininity, her social class standing and her whiteness. Ruth Frankenberg (1994) discusses the way that whites create an innocent racial self as a way to distance themselves from accusations of racism. In the white women I interviewed, several used this theme of naïve innocence as a credential of whiteness. Lucy's comment that she never saw a black person, but knew they were "out there-SOME where" speaks to a theme of whiteness: the creation of the "other". Bonilla-Silva details this as one of several ways linguistic strategies used by whites try to maintain a nonracial stance to soften the blows of racism.

I interviewed Susan Harris after her workday as a supervisor in a welfare agency. A slightly built red headed woman, Susan was dressed in loose fitted denim skirt, athletic shoes and a sweatshirt with the mascot of a local college. Her office had the British flag mounted on one entire wall and various pictures of her three sons posed in football jerseys. Over the next three hours, she described meeting her husband, getting married, raising three boys, getting a divorce and filing for bankruptcy. Recalling how she met her black husband, Susan:

That's how I met him, in a bar. When I saw Sydney that night across the room, it was instantaneous. I just gave into the attraction. His color never crossed my mind then or later. Took him home and he stayed two weeks. How's that? Isn't that like white trash? (Laughs) Meet in a bar and go home with him? I fell in love instantly. Susan Harris. 53 years old at interview. Married a Black construction worker in 1978.

Susan's tongue in cheek description of herself as "white trash" signals her awareness of stereotypes that circulate about white women with black men as well as her insight into the construction of "proper" sexual restraint among women.

This is a contrast to Marilyn Waters, who clings to her identity of a good white girl, at great expense. The mother of two daughters, Marilyn returned to her parents' home after divorcing her black husband, a meat cutter. She now attends college while working part-time. Marilyn was at an outdoor patio table on campus when we met for the interview looking harried and finishing a cigarette. With pale skin, her face looked much older than most women in their thirties. She had one eyebrow pierced with a silver barbell and one nostril pierced with a green stone. Her discussion of her husband's repeated philan- 
dering are peppered with Marilyn's emphasis her ladylike, polite behavior. It apparently did not occur to her to step out of the expectations for a "lady" to solve her marital problem. Notice how Marilyn uses gendered notions of whiteness to explain her inability to confront her husband on his extramarital affairs:

I didn't challenge him, it was such a hassle to confront him on stuff that I just looked the other way. I mean, he could just beat the shit out of me with words, so I just caved in and didn't ask about (the infidelities).

He was so good with words. He knew all those ways of fighting I didn't. I didn't do well. So do I think it was because he was black? Well I think part of it was (ETW: What part?).

That part they didn't teach us and nice white girls don't do well in that. We just get eaten up alive. We won't just call somebody a liar. We won't call them on it. Just like that. We don't do that. We weren't socialized that way. That's really it. It was to my detriment. But I'm a lot smarter now.

Marilyn Waters, 38, divorced her black husband after 18 years.

Marilyn not only relies on an image of "nice white girls" to explain her lack of assertiveness, she implicates me in her circle of white femininity with use of "us" and "we" to describe the hyper-politeness associated with "rarified southern white ladies” (Moon, 1998) She uses her innocence associated with whiteness and femininity to excuse her inability to take a stand. Then, Marilyn engages in essentialist discourse while noting, "they hear everything, they see everything". While it is unclear whether she attributing this extra sensory perception only to black men or to all blacks, it is clear that she draws upon essential thinking about both gender and race in her description of her ex-husband's alleged omnipotence. When she invokes the metaphor of "being eaten up alive", Marilyn relies on a familiar cultural representation, with a long history, which portrays black men, in general, and black sexuality, specifically, as predatory and all-consuming.

Dianne Kennedy, a walnut-color with freckles across her nose, has her hair pulled lightly to a bun at her neck. Wearing a white sweater draped over her shoulders, she looked right through me with coffee color eyes as she discussed her strategy for countering the stereotypes of black women, married across the color line, by describing her considerations when out in public with her white husband of twenty years:

One, you got to be more on your P's and Q's. You got to be careful how you act. I would never go out with Michael looking like a tramp. I would not. And I think that's from childhood growing up in the South. You think of a black man with a white woman she'd be all fat and nasty. A black woman with a white guy-that wouldn't look good. Where I come from, she's probably a working girl, if you know what I mean.

The awareness of stories that circulate and impressions others might have of an interracial couple works as a social control mechanism for Dianne who continues after twenty years to consider how strangers might misinterpret her for a prostitute. Dianne was not alone with this concern; two other black women interviewed also made pointed comments about being concerned about their appearance in public with their white husbands and their assumption that black women in the company of white men might be mistaken for prostitutes.

\section{Masculinity and Class on the Color Line}

Both black and white men who married across the color line expressed a common theme seldom articulated by the women I interviewed: their sense of male entitlement to resist social judgments about them. As summed up by one participant: "I don't pay attention to people who don't approve of me or Marsha. If they can't accept us, I don't want to know them”. Of course, most of the interviews revealed experiences that contradicted their imperviousness to social criticism. Floyd Barrington, for instance, recalled his first reaction to falling in love with his secretary years earlier, he said:

At the time, I told her, "No” I said, "I can’t do this. I really can't do this. She didn't understand. I tol her, from where I've been, who I am, I couldn't possibly possibly get involved with you. Not with a white woman. No.” I had been steeped in the "blacker than thou" mindset. Black men taking up with white women were suspicious and not to be trusted in the revolution.

Floyd Barrington, 52 years old at interview, married his white secretary in 1982.

Marty McVeigh, a police officer, is slightly built, with crew cut dark hair, brown eyes. He uses his whiteness as a claim of entitlement to date and marry his black wife. Recalling how he was attracted to her at their workplace:

So one day, I thought, (raises his voice to a higher pitch and cocks his head to indicate a voice in his head) Well, why not? Yeah. Who cares? I don't care. I can ask her out. Why not? It's a free country. I'm 21, free and white. Marty McVeigh, age 36 at interview. Married a black police officer in 1996.

Notice how Maurice Holland's beliefs about gender cannot be disentangled from his racial notions:

Umm I don't know about my baby, but my older two picked black people to marry. Whether she will or not I don't know. I don't know. (ETW: Will it matter to you?) Oh yeah (Talk about that to me).

Kris. Umm I hope she doesn't. I mean, I don't like white men. In general I don't. It would be hard. Yeah I would not be in favor of that. I couldn't know his white family's outlook, see, about racial things. And it could impact her. How would he raise kids? Ya know? I would be very, very upset if that were the case, a white man. I would actively discourage it. (ETW: What if your son married a white girl. Would you feel the same way?) No.

(ETW: Tell me about that) Because generally the wife adapts to and enters into the husband's world. I'd say that essentially is what it is. Ya know? And um, if my son married white, she'd come into his world. And I would imagine if my daughter married white, her life would be in his world. Just the way it is. Maurice married his white wife in 1967.

Ron Darby, a beefy redheaded salesman for a tile company greeted me at his wholesale warehouse dressed in a navy sports coat, white shirt, dark slacks and tasseled loafers. Ron lives with his black schoolteacher wife and two children in a middle class, neighborhood where the median home price is $\$ 390,000$. His parents "had no problems with Carla" and had always treated her brother, George, as "an honorary member" of the Darby family. Ron complains, however, that his parents favor his daughter over his son and he feels their increasing disinterest in his son is "racially" motivated.

It is so obvious. Mom thinks Molly is just like my sister. Always pointing out how Molly looks just like (my sister) Carrie but "with a tan". (As he tilted his head alternatively from ear to shoulder syncopating with a whiney tone to indicate a voice not his own) "How cute Molly is. (Tilt) How smart. (Tilts head other directions) What a Darby she is". (Tilts head back again 
to match the sing song rhythm of his discourse). I tell my Mom that Danny and Molly are both half Darby. Equal parts. Half the blood flowing in Danny is the Irish n Scottish blood from us. But she only sees the black in that boy. It's ridiculous. He isn't even darker than Molly. The older he gets, the more this black thing comes up with “em”. Ron Darby, married his black wife in 1987.

\section{Conclusion}

The study's focus on how participants use notions of gender and social class in describing their everyday experiences living on the color line illustrate that the concept of race itself is inextricably entangled with gender and social class. The interviews reveal the well worn provenance of cultural notions about the intersections of race, class and gender.

The participants expose how many deploy social class status to buffer and contest racial and gender challenges they encounter by membership in their racially integrated families.

The narratives illustrate that the stories people tell about their experiences in a racially integrated family reflect deeply embedded structures of their culture which are deployed to construct identity. How multiracial families signify racial dynamics to others and how they perform their racial and gender identities reveal much about commonsense understandings of the color line in contemporary society. Less obvious, but apparent through an examination stories that circulate as common wisdom is the fact that the color line depends as much upon the interlinking systems of gender and social class that are embedded in our institutions as upon ideology of white supremacy.

\section{REFERENCES}

Billingsley, A. (1992). Climbing Jacob's ladder: The enduring legacy of African American families. New York: Touchstone Books.

Bonilla-Silva, E. (2003). Racism without racists: Color-blind racism and the persistence of racial inequality in the United States. New York: Rowman and Littlefield.

Dalmage, H. (2000). Tripping on the color line: Black/white racially divided families in a racially divided world. New Brunswick: Rutgers Press.

Dalmage, H. (2004). The politics of Multiracialism: Challenging racial thinking. Albany: State University of New York Press.

Du Bois, W. E. B. (1967). The Philadelphia Negro: A social study. Philadelphia: University of Pennsylvania.

Ferber, A. L. (1998). White man falling: Race, gender and white supremacy. Lanham, MA: Rowman \& Littlefield.

Fields, J., \& Casper, L. M. (2001). America's families and living arrangements: March 2000. Current Population Reports P20-537. Washington DC: US Census Bureau.

Frankenberg, R. (1994). The social construction of whiteness: White women, race matters. Minneapolis: University of Minnesota Press.

Fu, V. K. (2001). Racial intermarriage pairings. Demography, 38, 147159. doi:10.1353/dem.2001.0011

Gubrium, J. F., \& Holstein, J. (2002). Handbook of interview research, context and method. Thousand Oaks: Sage Publication.

Harris, D. R., \& Ono, H. (2005). How many interracial marriages would there be if all groups were of equal size in all places. Social Science Research, 34, 236-251. doi:10.1016/j.ssresearch.2004.01.002

Heer, D. (1966). Negro-white marriages in the United States. In R. Staples (Ed.), The black family (pp. 292-311). New York: Wadsworth Publishing.

Heer, D. (1974). The prevalence of black-white marriage in the United States, 1960 and 1970. Journal of Marriage and the Family, 36, 246-258. doi:10.2307/351151

Kaba, A. J. (2011). Inter-ethnic/interracial romantic relationships in the United States: Factors responsible for the low rates of marriages between Blacks and Whites. Sociology Mind, 1, 121-129. doi:10.4236/sm.2011.13015

Lichter, D. T., \& Qian, Z. (2004). Marriage and family in a multiracial society. New York: Russell Sage Foundation.

McNamara, R., Tenpenis, M., \& Walton, B. (1999). Crossing the line. Interracial couples in the South. Westport, CO: Greenwood Press.

Monahan, T. P. (1976). An overview of statistics on interracial marriage in the United States, with data on its extent from 1963-1970. Journal of Marriage and the Family, 5, 223. doi: $10.2307 / 350382$

Omi, M., \& Winant, H. (1994). Racial formation in the United States from the 1960's to the 1990's (2nd ed.). New York: Routeledge.

Pascoe, P. (2010). What comes naturally: Miscegenation law and the making of race in the United States. Oxford: Oxford University Press.

Qian, Z. (1997). Breaking the racial barriers: Variations in interracial marriage between 1980 and 1990. Demography, 34, 263-276. doi:10.2307/2061704

Qian, Z. C. (1997). Breaking the racial barriers: Variations in interracial marriage between 1980 and 1990. Demography, 34, 263. doi: $10.2307 / 2061704$

Qian, Z. C. (2002). Race and social distance: Intermarriage with Non-Latino Whites. Race and Society, 5, 33-47. doi:10.1016/j.racsoc.2003.12.003

Rosenblatt, P., Karis, T., \& Powell, R. (1995). Multiracial couples: Black and White voices. Thousand Oaks: Sage Publications.

Sanjek, R. (1994). Intermarriage and the future of races in the United States. In Gregory, \& Sanjek (Eds.), Race. Piscataway, NJ: Rutgers University Press.

Tucker, M., \& Mitchell-Kernan, C. (1998). Psychological well-being and perceived marital opportunity among single African American, Latina, and White women. Journal of Comparative Family Studies, 29, 57 .

Wallenstein, P. (2002). Tell the court I love my wife: Race, marriage and law-An American history. New York: MacMillan.

Zebroski, S. (1999). Black-white intermarriages. The racial gender dynamics of support and opposition. Journal of Black Studies, 30, 123. doi:10.1177/002193479903000107 